\title{
Triterpenes and Flavonol Glucuronides from Oenothera cheiranthifolia
}

\author{
Tsutomu Nakanishi, ${ }^{* a}$, Yuka Inatomi, ${ }^{a}$ Hiroko Murata, ${ }^{a}$ Syun-suke Ishida, ${ }^{a}$ Yuri Fujino, ${ }^{a}$ \\ Kanako Miura, ${ }^{a}$ Yoshito Yasuno, ${ }^{a}$ Akira InadA, ${ }^{a}$ Frank A. Lang, ${ }^{b}$ and Jin MuratA ${ }^{c}$ \\ ${ }^{a}$ Faculty of Pharmaceutical Sciences, Setsunan University; 45-1 Nagaotoge-cho, Hirakata, Osaka 573-0101, Japan: \\ ${ }^{b}$ Department of Biology, Southern Oregon University; 1250 Siskiyou, Ashland, OR 97520-5071, U.S.A.: and ${ }^{c}$ Botanical \\ Gardens, Koishikawa, Graduate School of Science, The University of Tokyo; 3-7-1 Hakusan, Bunkyo-ku, Tokyo 112-0001, \\ Japan. Received August 17, 2006; accepted October 22, 2006
}

\begin{abstract}
A new ursane-type triterpene, named as cheiranthic acid (1), was isolated from the MeOH extract of whole plants of Oenothera cheiranthifolia (Onagraceae) along with an isomeric pair of known oleanane- and ursanetype triterpenes (arjunolic acid and asiatic acid) and three flavonol glucuronide analogues (quercetin 3-O-glucuronide, its $n$-butyl ester, and myricetin 3-O-glucuronide). Their structures were elucidated based on spectroscopic evidence.
\end{abstract}

Key words Oenothera cheiranthifolia; Onagraceae; cheiranthic acid; ursane-type triterpene; oleanane-type triterpene; flavonol glucuronide

Oenothera cheiranthifolia (Onagraceae), called BeachPrimrose in English, is a perennial that has wiry and prostrate stems (radiating from a central rosette of leaves) and bright yellow flowers (in a small-flowered form with petals to one-third inch long) and grows flat on the sandy beach from Point Conception, Santa Barbara County, California to Coos Bay, Oregon. ${ }^{1)}$

As a part of a series of our phytochemical studies on western North American plants, chemical components of the $\mathrm{MeOH}$ extract obtained from whole plants of $O$. cheiranthifolia were investigated and as a result, a new ursane-type triterpene named as cheiranthic acid (1) was isolated together with an isomeric pair of known oleanane- and ursane-type triterpenes, arjunolic acid (2) and asiatic acid (3), and three known flavonols, 3-O- $\beta$-D-glucuronides of quercetin (4) and myricetin (5) and the $n$-butyl ester of $4(6)$. This paper describes the isolation and structural elucidation of these components.

Each of the EtOAc- and $n$-BuOH soluble parts obtained from the $\mathrm{MeOH}$ extract was separated by a combination of silica gel, octadecyl silica gel (ODS), and Sephadex LH-20 column chromatography and HPLC separation to isolate each of a new (1) and two known $(\mathbf{2}, \mathbf{3})$ triterpenes and an abundant flavonol component (4) from the EtOAc soluble part and three flavonol glucuronide analogues $(4-6)$ from the $n$ $\mathrm{BuOH}$ soluble part.

A new triterpene, cheiranthic acid (1), a colorless glassy solid, $[\alpha]_{\mathrm{D}}+81.1^{\circ}\left(\mathrm{CHCl}_{3}\right)$, gave the molecular ion peak at $\mathrm{m} / \mathrm{z} 486(13 \%)$ along with abundant and significant fragment ions such as at $\mathrm{m} / \mathrm{z} 248(100 \%)$ and at $\mathrm{m} / \mathrm{z} 203(45 \%)$ in electron impact (EI)-MS. Furthermore, the molecular formula was determined as $\mathrm{C}_{30} \mathrm{H}_{46} \mathrm{O}_{5}$ based on the high resolution (HR)-MS data $(m / z 486.334)$ of the $\mathrm{M}^{+}$ion. The ${ }^{1} \mathrm{H}-\mathrm{NMR}$ spectrum of 1 exhibited signals due to four tertiary methyls [ $\delta 0.85$ (26-Me), 1.08 (24-Me), 1.11 (27-Me), and 1.35 (25$\mathrm{Me})]$, two secondary methyls $[\delta 0.90(\mathrm{~d}, J=6.6 \mathrm{~Hz}, 29-\mathrm{Me})$ and $0.95(\mathrm{~d}, J=6.3 \mathrm{~Hz}, 30-\mathrm{Me})]$, a hydroxymethylene $[\delta 3.44$ $(1 \mathrm{H}, \mathrm{d}, J=10.4 \mathrm{~Hz})$ and $3.75(1 \mathrm{H}, \mathrm{d}, J=10.4 \mathrm{~Hz}), 23-$ $\left.\mathrm{CH}_{2} \mathrm{OH}\right]$, an oxygenated methine $[\delta 3.92(\mathrm{dd}, J=12.0,5.0$, $3 \alpha$-ax. H)], and an olefinic proton $[\delta 5.27(1 \mathrm{H}, \mathrm{t}$-like, $J=3.5 \mathrm{~Hz}$ ). The ${ }^{13} \mathrm{C}-\mathrm{NMR}$ spectrum of $\mathbf{1}$ indicated that $\mathbf{1}$ was constituted by thirty carbon atoms including a cyclic ketone

on a cyclohexane ring $\left[\delta_{\mathrm{C}} 211.9(\mathrm{C}-1)\right],{ }^{2)}$ a carboxyl carbon $\left[\delta_{\mathrm{C}} 181.4(\mathrm{C}-28)\right],{ }^{2)}$ and two olefinic carbons $\left[\delta_{\mathrm{C}} 126.4(\mathrm{C}-\right.$ $12)$ and $137.2(\mathrm{C}-13)]$. The above-mentioned spectral evidence suggested that $\mathbf{1}$ is a triterpenic acid having an ursolic acid framework and an urs-12-en-28-oic acid structure proposed for 1 was further corroborated by the following EIand HR-EI-MS spectral evidence: the molecular ion underwent the retro-Diels-Alder fragmentation of the $12-13$ double bond in the ring $\mathrm{C}$ to yield a typical fragment ion $(\mathrm{m} / \mathrm{z}$ 248.177 observed for $\mathrm{C}_{16} \mathrm{H}_{24} \mathrm{O}_{2}$; the base peak), arising from the $\mathrm{D} / \mathrm{E}$ ring of $1 .^{3)}$ Furthermore, the second abundant fragment ion observed at $\mathrm{m} / \mathrm{z} 203(45 \%)$ in the EI-MS and at $\mathrm{m} / \mathrm{z}$ 203.179 (Calcd for $\mathrm{C}_{15} \mathrm{H}_{23}: 203.180$ ) in the HR-EI-MS seemed to arise from the base peak by the loss of a carboxyl unit, which also supports $\mathbf{1}$ having an ursolic acid skeleton. To determine the precise structure for $\mathbf{1},{ }^{1} \mathrm{H}-$ and ${ }^{13} \mathrm{C}-\mathrm{NMR}$ analyses were performed with the aid of two dimensional (2D)-NMR $\left[{ }^{1} \mathrm{H}-{ }^{1} \mathrm{H}\right.$ shift-correlation spectroscopy (COSY),

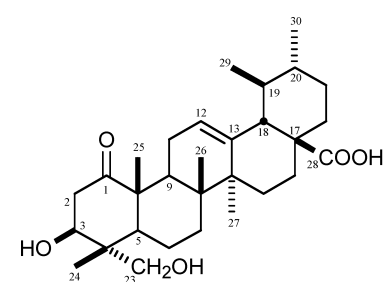

1

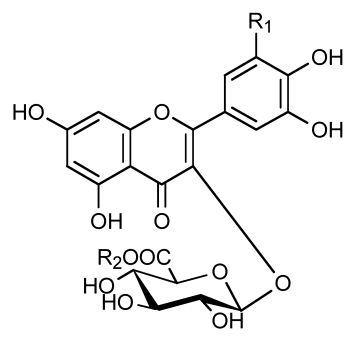

$4: \mathrm{R}_{1}=\mathrm{H}, \quad \mathrm{R}_{2}=\mathrm{H}$

$5: \mathrm{R}_{1}=\mathrm{OH}, \mathrm{R}_{2}=\mathrm{H}$

$6: \mathrm{R}_{1}=\mathrm{H}, \quad \mathrm{R}_{2}=n$-butyl

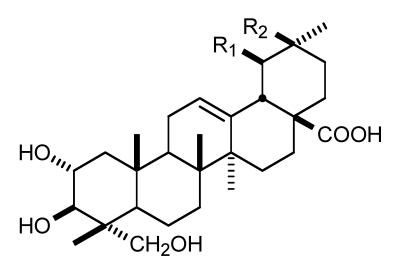

2: $\mathrm{R}_{1}=\mathrm{H}, \quad \mathrm{R}_{2}=\mathrm{Me}$

$3: \mathrm{R}_{1}=\mathrm{Me}, \mathrm{R}_{2}=\mathrm{H}$ 
Table 1. ${ }^{1} \mathrm{H}(600 \mathrm{MHz})$ - and ${ }^{13} \mathrm{C}(150 \mathrm{MHz})-\mathrm{NMR}$ Data of $\mathbf{1}$ in $\left.\mathrm{CDCl}_{3}{ }^{a}\right)$

\begin{tabular}{|c|c|c|}
\hline No. & ${ }^{1} \mathrm{H}-\mathrm{NMR}$ & ${ }^{13} \mathrm{C}-\mathrm{NMR}$ \\
\hline $\mathrm{C}_{1}$ & & 211.9 \\
\hline $\mathrm{C}_{2}$ & $\begin{array}{l}2.40(1 \mathrm{H}, \mathrm{dd}, J=12.0,5.0, \alpha \text {-eq.H }) \\
3.05(1 \mathrm{H}, \mathrm{dd}, J=12.0,12.0, \beta \text {-ax.H })\end{array}$ & 43.3 \\
\hline $\mathrm{C}_{3}$ & $3.92(1 \mathrm{H}, \mathrm{dd}, J=12.0,5.0, \alpha$-ax.H $)$ & 75.6 \\
\hline $\mathrm{C}_{4}$ & & 42.4 \\
\hline $\mathrm{C}_{5}$ & $1.12(1 \mathrm{H})^{b)}$ & 48.5 \\
\hline $\mathrm{C}_{6}$ & $1.42(1 \mathrm{H})^{b)}, 1.54(1 \mathrm{H})^{b)}$ & 18.1 \\
\hline $\mathrm{C}_{7}$ & $1.30(1 \mathrm{H})^{b)}, 1.43(1 \mathrm{H})^{b)}$ & 32.6 \\
\hline $\mathrm{C}_{8}$ & & 39.4 \\
\hline $\mathrm{C}_{9}$ & $2.23(1 \mathrm{H}, \mathrm{dd}, J=11.4,5.4, \alpha$-ax.H $)$ & 38.8 \\
\hline $\mathrm{C}_{10}$ & & 51.9 \\
\hline $\mathrm{C}_{11}$ & $1.84(1 \mathrm{H})^{b)}, 2.40(1 \mathrm{H})^{b)}$ & 25.1 \\
\hline $\mathrm{C}_{12}$ & $5.27(1 \mathrm{H}, \mathrm{t}$-like, $J=3.5)$ & 126.4 \\
\hline $\mathrm{C}_{13}$ & & 137.2 \\
\hline $\mathrm{C}_{14}$ & & 42.2 \\
\hline $\mathrm{C}_{15}$ & $1.06(1 \mathrm{H})^{b)}, 1.84(1 \mathrm{H})^{b)}$ & 28.0 \\
\hline $\mathrm{C}_{16}$ & $\begin{array}{l}1.68(1 \mathrm{H}, \beta \text {-eq.H })^{b}, 2.02(1 \mathrm{H}, \mathrm{ddd}, J=13.8,13.8,4.8, \\
\alpha \text {-ax.H) }\end{array}$ & 24.1 \\
\hline $\mathrm{C}_{17}$ & & 48.0 \\
\hline $\mathrm{C}_{18}$ & $2.20(1 \mathrm{H}, \mathrm{d}, J=11.4, \beta-\mathrm{H})$ & 52.8 \\
\hline $\mathrm{C}_{19}$ & $1.33(1 \mathrm{H})^{b)}$ & 39.0 \\
\hline $\mathrm{C}_{20}$ & $1.01(1 \mathrm{H}, \mathrm{m})$ & 39.0 \\
\hline $\mathrm{C}_{21}$ & $1.28(1 \mathrm{H})^{b)}, 1.51(1 \mathrm{H})^{b)}$ & 30.6 \\
\hline $\mathrm{C}_{22}$ & $1.66(1 \mathrm{H})^{b)}, 1.72(1 \mathrm{H}, \mathrm{ddd}, J=13.0,13.0,3.5)$ & 36.6 \\
\hline $\mathrm{C}_{23}$ & $3.44(1 \mathrm{H}, \mathrm{d}, J=10.4 \mathrm{~Hz}), 3.75(1 \mathrm{H}, \mathrm{d}, J=10.4)$ & 70.9 \\
\hline $\mathrm{C}_{24}$ & $1.08(3 \mathrm{H}, \mathrm{s})$ & 12.1 \\
\hline $\mathrm{C}_{25}$ & $1.35(3 \mathrm{H}, \mathrm{s})$ & 15.6 \\
\hline $\mathrm{C}_{26}$ & $0.85(3 \mathrm{H}, \mathrm{s})$ & 17.9 \\
\hline $\mathrm{C}_{27}$ & $1.11(3 \mathrm{H}, \mathrm{s})$ & 23.5 \\
\hline $\mathrm{C}_{28}$ & & 181.4 \\
\hline $\mathrm{C}_{29}$ & $0.90(3 \mathrm{H}, \mathrm{d}, J=6.6)$ & 17.0 \\
\hline $\mathrm{C}_{30}$ & $0.95(3 \mathrm{H}, \mathrm{d}, J=6.3)$ & 21.1 \\
\hline
\end{tabular}

a) Chemical shifts are shown in ppm, coupling constants in Hz. b) Signals are overlapped by other signal(s) and therefore, their multiplicities could not be determined.

heteronuclear multiquantum coherence (HMQC), nuclear Overhauser enhancement spectroscopy (NOESY), and heteronuclear multiple bond connectivity (HMBC)] experiments and all protons and carbons were successfully assigned as shown in Table 1. Based on the established ${ }^{1} \mathrm{H}$ - and ${ }^{13} \mathrm{C}$-assignments (Table 1), a whole structure for $\mathbf{1}$ was defined as shown by formula $\mathbf{1}$ and some important parts, i.e., key points, in the structural elucidation are explained as follows. The COSY spectrum of $\mathbf{1}$ showed the presence of characteristic carbon linkages of $\mathrm{C}_{(2)} \mathrm{H}_{2}-\mathrm{C}_{(3)} \mathrm{H}(\mathrm{OH})$ and $\mathrm{C}_{(18)} \mathrm{H}-$ $\mathrm{C}_{(19)} \mathrm{H}\left(\mathrm{CH}_{3}\right)-\mathrm{C}_{(20)} \mathrm{H}\left(\mathrm{CH}_{3}\right)$ in $\mathbf{1}$. These COSY data, when considered with the HMBC correlations observed in 1 (Fig. 1), suggested that a plane structure of $\mathbf{1}$ is the same as that depicted in Fig. 1. Finally, the steric structure of $\mathbf{1}$ was clarified based on the following NMR evidence. The large coupling constant $(12.0 \mathrm{~Hz})$ observed between a proton $(\delta 3.05)$ of 2 $\mathrm{H}_{2}$ and 3-H $(\delta 3.92)$ shows that these two protons are in a diaxial relationship, consistent with the $2 \beta$ - and $3 \alpha$-oriented protons. Needless to say, the $3-\mathrm{OH}$ group has a $\beta$-equatorial configuration. The presence of a series of cross peaks in the NOESY between $24-\mathrm{Me}$ and $25-\mathrm{Me}$, between $24-\mathrm{Me}$ and $2 \beta$ $\mathrm{H}$, between $25-\mathrm{Me}$ and $2 \beta-\mathrm{H}$, and between $24-\mathrm{Me}$ and $23-$ $\mathrm{CH}_{2} \mathrm{OH}$ suggested that the methyl attached at $\mathrm{C}-4$ is oriented to $\beta$-axial $(=24-\mathrm{Me})$ and the $\mathrm{CH}_{2} \mathrm{OH}$ group is $\alpha$-equatorial $\left(=23-\mathrm{CH}_{2} \mathrm{OH}\right)$. In addition, two characteristic and significant NOESY cross peaks were observed between $9 \alpha-\mathrm{H}$ and $27 \alpha$ $\mathrm{Me}$ and between the olefinic proton $(=12-\mathrm{H})$ and $18-\mathrm{H}$, in-

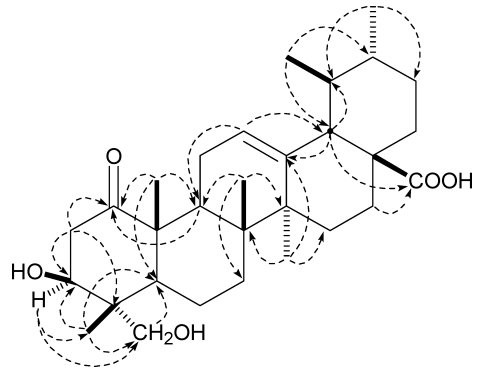

Fig. 1. The Key HMBC Correlations of $\mathbf{1}$

dicative of the steric feature around the B-, C-, D-, and Erings of 1. Especially, based on the occurrence of the cross peak between $12-\mathrm{H}$ and $18-\mathrm{H}$, the configuration of $18-\mathrm{H}$ is considered $\beta$-equatorial on the $\mathrm{D}$-ring $(=\beta$-axial on the $\mathrm{E}$ ring). This result also shows that the D/E-ring juncture of $\mathbf{1}$ is cis. Furthermore, the large coupling constant between $18-\mathrm{H}$ and $19-\mathrm{H}\left(J_{18,19}=11.4 \mathrm{~Hz}\right)$ indicates that $18-\mathrm{H}$ and $19-\mathrm{H}$ are in a diaxial relation on the E-ring, that is, $19-\mathrm{H}$ is oriented to $\alpha$-axial whereas the methyl at $\mathrm{C} 19$ (C-29) is $\beta$-equatorial. The above-mentioned accumulated evidence revealed $\mathbf{1}$ to be shown by the structural formula 1 with an ursane $(=\alpha$ amyrin) framework.

The isolated arjunolic acid was defined as formula $\mathbf{2}$ based on our own structural elucidation by EI- and HR-EI-MS and ${ }^{1} \mathrm{H}$ - and ${ }^{13} \mathrm{C}-\mathrm{NMR}$ (2D) spectral studies. Furthermore, it was identified by comparison of the ${ }^{1} \mathrm{H}$ - and ${ }^{13} \mathrm{C}-\mathrm{NMR}$ data (in pyridine- $d_{5} ; 600$ and $150 \mathrm{MHz}$, respectively) with those reported for arjunolic acid. ${ }^{4,5}$

The isolated asiatic acid was decided as formula $\mathbf{3}$ in a similar manner as in the structural elucidation of $\mathbf{2}$ and further identified by direct comparison of ${ }^{1} \mathrm{H}$ - and ${ }^{13} \mathrm{C}-\mathrm{NMR}$ spectra (in $\mathrm{CD}_{3} \mathrm{OD} ; 600$ and $150 \mathrm{MHz}$, respectively) with authentic asiatic acid commercially obtained.

The isolated flavonol glucuronide (4) gave the quasi-molecular ion, $(\mathrm{M}-\mathrm{H})^{-}$at 477 and a significant fragment ion, (the aglycone-H) ${ }^{-}$at $\mathrm{m} / \mathrm{z} 301$ in the negative (=neg.) ion FAB-MS spectrum. Based on these MS data together with the ${ }^{1} \mathrm{H}$ - and ${ }^{13} \mathrm{C}-\mathrm{NMR}$ (in DMSO- $d_{6} ; 600$ and $150 \mathrm{MHz}$, respectively) and these $2 \mathrm{D}$ analyses the structure was assigned to formula 4. Moreover, the identity with quercetin $3-O-\beta$-Dglucuronide was confirmed by comparison of the ${ }^{13} \mathrm{C}-\mathrm{NMR}$ data with the reported data. ${ }^{\text {) }}$

The second flavonol glucuronide (5) isolated was identified with myricetin 3-O- $\beta$-D-glucuronide by comparison of its neg. ion FAB-MS, ${ }^{1} \mathrm{H}-$ and ${ }^{13} \mathrm{C}-\mathrm{NMR}$ (in DMSO- $d_{6}$; 600 and $150 \mathrm{MHz}$, respectively) with those previously reported. ${ }^{7)}$

The last flavonol glucuronide analogue (6) isolated gave the $[\mathrm{M}-\mathrm{H}]^{-}$ion peak at 533 in the neg. ion FAB-MS. The corresponding HR spectrum revealed the molecular formula to be $\mathrm{C}_{25} \mathrm{H}_{26} \mathrm{O}_{13}$. In addition, the EI- and HR-EI-MS spectra of 6 exhibited a significant fragment ion at $\mathrm{m} / z 302$ as the base peak, because of the aglycone of $\mathrm{C}_{15} \mathrm{H}_{10} \mathrm{O}_{7} .{ }^{1} \mathrm{H}$ - and ${ }^{13} \mathrm{C}$ NMR assignments (see Experimental) were carried out with the aid of the detailed 2D analyses (COSY, HMQC, NOESY, and HMBC) and the resulting NMR evidence revealed 6 to be defined as quercetin 3-O-(6"-n-butyl glucuronide). This flavonol derivative has been already isolated from leaves of Parthenocissus tricuspidata (Vitaceae). ${ }^{8)}$ This report appears the second instance of its isolation from natural sources. 
However, the question has been raised whether this butyl ester is a genuine naturally occurring product or an artificial compound derived from quercetin 3-O-glucuronide during the extraction procedure with $n$-butanol.

\section{Experimental}

General ${ }^{1} \mathrm{H}$ - and ${ }^{13} \mathrm{C}$-NMR spectra were measured on a JEOL JNMECA 600 spectrometer $\left({ }^{1} \mathrm{H}\right.$ at $600 \mathrm{MHz}$ and ${ }^{13} \mathrm{C}$ at $\left.150 \mathrm{MHz}\right)$. Chemical shifts are given in $\delta$ values (ppm) relative to tetramethylsilane (TMS) as internal standard. EI- and HR-EI-MS spectra (at $30 \mathrm{eV}$ ), along with FAB- and HR-FAB-MS spectra in negative mode (matrix: triethanolamine or glycerin), were obtained by JEOL JMS-700T spectrometer. Optical rotations were determined on a JASCO DIP-140 polarimeter. For column chromatography, silica gel 60 (230 - 400 mesh, Merck), Chromatorex ODS DM1020T (100-200 mesh, Fuji Silysia), and Sephadex LH-20 (Amersham Biosciences) were used. Kiesel gel $60 \mathrm{~F}_{254}$ (Merck) and RP-18 $\mathrm{F}_{254}$ (Merck) were used for analytical TLC. Preparative HPLC was performed on a JAI LC-918 instrument with an RI-50 differential refractometer and a JAIGELODS column. An authentic asiatic acid used in this work was commercially obtained from Extrasynthese in France.

Plant Material Whole plants of $O$. cheiranthifolia were collected at a sandy beach in Oregon, U.S.A., in July 1997. A voucher specimen (Murata J. et al., No. 97027) was deposited in the Herbarium, Botanical Gardens, The University of Tokyo (TI), Japan.

Extraction and Isolation The whole plants of $O$. cheiranthifolia were soaked in acetone (2.01) and the plant materials (118.0 g) after soaking were extracted three times with $\mathrm{MeOH}$ (each 2.01) at room temperature for 15, 9, and $9 \mathrm{~d}$ in turn. The resulting $\mathrm{MeOH}$ extract $(22.2 \mathrm{~g})$ was suspended in water $(500 \mathrm{ml})$ and extracted four times with EtOAc $(500 \mathrm{ml} \times 1$ then $250 \mathrm{ml} \times 3)$ and subsequently, three times with $n-\mathrm{BuOH}(300 \mathrm{ml} \times 3)$ to afford EtOAc $(3.9 \mathrm{~g})$ and $n-\mathrm{BuOH}(8.1 \mathrm{~g})$ extracts, respectively. Most $(3.8 \mathrm{~g})$ of the EtOAc extract was subjected to column chromatography on silica gel $(190.0 \mathrm{~g})$ eluted successively with $\mathrm{CHCl}_{3}-\mathrm{MeOH}(20: 1$; total $1050 \mathrm{ml}$ ) [giving 30 fractions of Nos. 1 to 30], (10:1; total $1320 \mathrm{ml})$ [giving 16 fractions of Nos. 31 to 46], the lower phase of $\mathrm{CHCl}_{3}-\mathrm{MeOH}-\mathrm{H}_{2} \mathrm{O}(7: 3: 1$; total 1.541) [giving 41 fractions of Nos. 47 to 87], the lower phase of $\mathrm{CHCl}_{3}-\mathrm{MeOH}-\mathrm{H}_{2} \mathrm{O}$ ( $65: 35: 10$; total $440 \mathrm{ml})$; [giving 6 fractions of Nos. 88 to 93], and a mixture solvent of $\mathrm{CHCl}_{3}-\mathrm{MeOH}-\mathrm{H}_{2} \mathrm{O}(6: 4: 1$; total 1.11$)$; [giving 20 fractions of Nos. 94 to 113]. The fractions of Nos. 18 and $19(20.6 \mathrm{mg})$ were collected and subjected to reversed-phase (ODS Chromatrex; $5.1 \mathrm{~g}$ ) chromatography eluted with $\mathrm{MeOH}-\mathrm{H}_{2} \mathrm{O}(3: 1)$ [giving 9 fractions $(10 \mathrm{ml}$ per fraction)] and the resulting third fraction gave compound $\mathbf{1}(2.2 \mathrm{mg})$. The fractions of Nos. $28-32(85.6 \mathrm{mg})$ were collected and rechromatographed over ODS Chromatrex $(8.2 \mathrm{~g})$ eluted with $\mathrm{MeOH}-\mathrm{H}_{2} \mathrm{O}(3: 1)$ [giving 10 fractions $(10 \mathrm{ml}$ per fraction)] and the resulting third fraction $(15.7 \mathrm{mg}$ ) was subjected to preparative HPLC separation [JAIGEL-ODS column; an eluting agent, $80 \%$ aqueous (=aq.) $\mathrm{MeOH}$; a rate of flow, $5 \mathrm{ml} / \mathrm{min}$ ] to yield compounds $2(4.3 \mathrm{mg})$ and $3(5.6 \mathrm{mg})$. The fractions of Nos. $100-107(146.8 \mathrm{mg})$ were collected and further column-chromatographed over ODS Chromatrex (15.6 g) [eluting with $\mathrm{CH}_{3} \mathrm{CN}-\mathrm{H}_{2} \mathrm{O}(1: 7)$ and giving 28 fractions (5 ml per fraction)] and the resulting fractions $9-11$ gave compound $4(38.2 \mathrm{mg})$ in pure form. An aliquot $(3.8 \mathrm{~g}$ ) of the $n-\mathrm{BuOH}$ extract (vide ante) was chromatographed over ODS $(192 \mathrm{~g})$, and eluted $(100 \mathrm{ml}$ per fraction) successively with $\mathrm{CH}_{3} \mathrm{CN}: \mathrm{H}_{2} \mathrm{O}(1: 4)$ [giving 15 fractions (Nos. 1 to 15$)$ ], $\mathrm{CH}_{3} \mathrm{CN}: \mathrm{H}_{2} \mathrm{O}$ $(1: 2)$ [giving 13 fractions (Nos. 16 to 28$)$ ], $\mathrm{CH}_{3} \mathrm{CN}: \mathrm{H}_{2} \mathrm{O}(1: 1)$ [giving 4 fractions (Nos. 29 to 32)], and $\mathrm{CH}_{3} \mathrm{CN}$ [giving 2 fractions (Nos. 33, 34)]. The fractions of Nos. 4-6 $(937.7 \mathrm{mg})$ eluted with $\mathrm{CH}_{3} \mathrm{CN}: \mathrm{H}_{2} \mathrm{O}(1: 4)$ were combined and subjected to a Sephadex LH-20 column eluted with $30 \%$ aq $\mathrm{MeOH}$ to afford 17 fractions ( $30 \mathrm{ml}$ per fraction), the tenth fraction of which gave pure $5(14.7 \mathrm{mg})$. The fractions of Nos. 9 and 10 , eluted with $\mathrm{CH}_{3} \mathrm{CN}: \mathrm{H}_{2} \mathrm{O}(1: 4)$, corresponded to pure $4(200.1 \mathrm{mg})$. The fractions of Nos. 22 and $23(77.8 \mathrm{mg})$ eluted with $\mathrm{CH}_{3} \mathrm{CN}: \mathrm{H}_{2} \mathrm{O}(1: 2)$ were further separated on Sep-Pak $\mathrm{C}_{18}$ column (Waters; $10 \mathrm{~g}$ ) eluted subsequently with $\mathrm{CH}_{3} \mathrm{CN}: \mathrm{H}_{2} \mathrm{O}(2: 3)$ [giving fractions of No. 1 to No. 7 (5 $\mathrm{ml}$ per fraction)] and with $\mathrm{CH}_{3} \mathrm{CN}: \mathrm{H}_{2} \mathrm{O}(1: 1)$ [giving fraction No. 8 (a $10 \mathrm{ml}$ amount), fractions Nos. 9 and 10 (each $20 \mathrm{ml}$ amount)] and the resulting fraction No. 9 yielded 6 (19.6 mg).

Cheiranthic Acid (1): A colorless glassy solid, $[\alpha]_{\mathrm{D}}+81.1^{\circ}(c=0.5$, $\mathrm{CHCl}_{3}$ ). EI-MS (30 eV) m/z (\%): $486\left(13, \mathrm{M}^{+}\right), 248$ (100), 219 (10), 203 (45), 133 (23). HR-EI-MS $m / z$ : 486.334 (Calcd for $\mathrm{C}_{30} \mathrm{H}_{46} \mathrm{O}_{5}, \mathrm{M}^{+}:$486.335), 248.177 (Calcd for $\mathrm{C}_{16} \mathrm{H}_{24} \mathrm{O}_{2}:$ 248.178), 203.179 (Calcd for $\mathrm{C}_{15} \mathrm{H}_{23}$, $\mathrm{C}_{16} \mathrm{H}_{24} \mathrm{O}_{2}-\mathrm{COOH}: 203.180$ ). ${ }^{1} \mathrm{H}$ - and ${ }^{13} \mathrm{C}-\mathrm{NMR}$ : Given in Table1.
2: EI-MS $(30 \mathrm{eV}) \mathrm{m} / z(\%): 488\left(0.7, \mathrm{M}^{+}\right), 248(100), 219$ (7.6), 203 (76.6), 191 (11.9), 133 (15.7). HR-EI-MS $m / z: 488.349$ (Calcd for $\mathrm{C}_{30} \mathrm{H}_{48} \mathrm{O}_{5}$, $\mathrm{M}^{+}$: 488.350), 248.178 (Calcd for $\mathrm{C}_{16} \mathrm{H}_{24} \mathrm{O}_{2}:$ 248.178), 203.180 (Calcd for $\left.\mathrm{C}_{15} \mathrm{H}_{23}, \mathrm{C}_{16} \mathrm{H}_{24} \mathrm{O}_{2}-\mathrm{COOH}: 203.180\right)$. The ${ }^{1} \mathrm{H}$ - and ${ }^{13} \mathrm{C}-\mathrm{NMR}$ spectral data of 2 were in agreement with those reported for arjunolic acid. ${ }^{4,5}$

3: EI-MS $(30 \mathrm{eV}) \mathrm{m} / \mathrm{z}(\%): 488\left(1.3, \mathrm{M}^{+}\right), 248(100), 219$ (12.5), 203 (52.8), 191 (15.2), 133 (26.8). HR-EI-MS $m / z$ : 488.350 (Calcd for $\mathrm{C}_{30} \mathrm{H}_{48} \mathrm{O}_{5}$, $\mathrm{M}^{+}$: 488.350), 248.177 (Calcd for $\mathrm{C}_{16} \mathrm{H}_{24} \mathrm{O}_{2}:$ 248.178), 203.180 (Calcd for $\mathrm{C}_{15} \mathrm{H}_{23}, \mathrm{C}_{16} \mathrm{H}_{24} \mathrm{O}_{2}-\mathrm{COOH}: 203.180$ ). The structure of $\mathbf{3}$ was confirmed by direct comparison of ${ }^{1} \mathrm{H}$ - and ${ }^{13} \mathrm{C}-\mathrm{NMR}$ spectra (in $\mathrm{MeOH}-d_{4} ; 600$ and $150 \mathrm{MHz}$, respectively) with an authentic sample of asiatic acid.

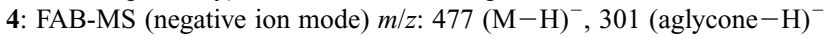
${ }^{1} \mathrm{H}-\mathrm{NMR}$ (in DMSO- $\left.d_{6} ; 600 \mathrm{MHz}\right): 3.26-3.41\left(3 \mathrm{H}, \mathrm{m}, 2^{\prime \prime}, 3^{\prime \prime}, 4^{\prime \prime}-\mathrm{Hs}\right), 3.58$ $\left(1 \mathrm{H}, \mathrm{d}, J=9.6 \mathrm{~Hz}, 5^{\prime \prime}-\mathrm{H}\right), 5.51\left(1 \mathrm{H}, \mathrm{d}, J=7.2 \mathrm{~Hz}, 1^{\prime \prime}-\mathrm{H}\right), 6.21(1 \mathrm{H}, \mathrm{d}$, $J=2.0 \mathrm{~Hz}, 6-\mathrm{H}), 6.41(1 \mathrm{H}, \mathrm{d}, J=2.0 \mathrm{~Hz}, 8-\mathrm{H}), 6.84\left(1 \mathrm{H}, \mathrm{d}, J=8.8 \mathrm{~Hz}, 5^{\prime}-\mathrm{H}\right)$, $7.53\left(1 \mathrm{H}, \mathrm{d}, J=2.0 \mathrm{~Hz}, 2^{\prime}-\mathrm{H}\right), 7.61\left(1 \mathrm{H}, \mathrm{dd}, J=8.8,2.0 \mathrm{~Hz}, 6^{\prime}-\mathrm{H}\right), 12.57(1 \mathrm{H}$, $\mathrm{s}, 5-\mathrm{OH}$ ). The ${ }^{13} \mathrm{C}-\mathrm{NMR}$ data (in DMSO- $d_{6} ; 150 \mathrm{MHz}$ ) of 4 was consistent with those (in DMSO- $d_{6} ; 75.47 \mathrm{MHz}$ ) reported for quercetin 3- $O$ - $\beta$-D-glucuronide. $\left.{ }^{6}\right)$

5: FAB- and HR-FAB-MS (negative ion mode) $\mathrm{m} / \mathrm{z}$ : 493.062 [Calcd for $\mathrm{C}_{21} \mathrm{H}_{17} \mathrm{O}_{14},(\mathrm{M}-\mathrm{H})^{-}$: 493.062], 317 (aglycone-H) $^{-}$. EI- and HR-EI-MS (\%): 318.037 (47) [Calcd for $\mathrm{C}_{15} \mathrm{H}_{10} \mathrm{O}_{8}$, (aglycone) ${ }^{+}$: 318.037 ], 170 (100). ${ }^{1} \mathrm{H}-\mathrm{NMR}$ (in DMSO- $d_{6}$; $600 \mathrm{MHz}$ ): $3.27\left(1 \mathrm{H}, \mathrm{dd}, J=9.0,8.4 \mathrm{~Hz}, 3^{\prime \prime}-\mathrm{H}\right), 3.40$ $\left(1 \mathrm{H}, \mathrm{dd}, J=8.4,7.8 \mathrm{~Hz}, 2^{\prime \prime}-\mathrm{H}\right), 3.42\left(1 \mathrm{H}, \mathrm{dd}, J=9.6,9.0 \mathrm{~Hz}, 4^{\prime \prime}-\mathrm{H}\right), 3.55(1 \mathrm{H}$, d, $\left.J=9.6 \mathrm{~Hz}, 5^{\prime \prime}-\mathrm{H}\right), 5.50\left(1 \mathrm{H}, \mathrm{d}, J=7.8 \mathrm{~Hz}, 1^{\prime \prime}-\mathrm{H}\right), 6.20(1 \mathrm{H}, \mathrm{d}, J=1.8 \mathrm{~Hz}, 6-$ H), $6.38(1 \mathrm{H}, \mathrm{d}, J=1.8 \mathrm{~Hz}, 8-\mathrm{H}), 7.19\left(2 \mathrm{H}, \mathrm{s}, 2^{\prime}-, 6^{\prime}-\mathrm{Hs}\right), 12.59(1 \mathrm{H}, \mathrm{s}, 5-$ $\mathrm{OH})$. Finally, 5 was identified by comparing its FAB-MS (negative ion mode), ${ }^{1} \mathrm{H}$ - and ${ }^{13} \mathrm{C}-\mathrm{NMR}$ (in DMSO- $d_{6} ; 600$ and $150 \mathrm{MHz}$, respectively) spectral data with those reported for myricetin 3-O- $\beta$-D-glucuronide. ${ }^{7)}$

Quercetin 3-O-(6"-n-Butyl Glucuronide) (6): HR-FAB-MS (negative ion mode) $\mathrm{m} / z$ : 533.129 [Calcd for $\mathrm{C}_{25} \mathrm{H}_{25} \mathrm{O}_{13},(\mathrm{M}-\mathrm{H})^{-}:$533.130]. EIand HR-EI-MS m/z (\%): 302.044 (100) [Calcd for $\mathrm{C}_{15} \mathrm{H}_{10} \mathrm{O}_{7}$, (aglycone) ${ }^{+}$: 302.043$] .{ }^{1} \mathrm{H}-\mathrm{NMR}$ (in $\mathrm{CDCl}_{3} ; 600 \mathrm{MHz}$ ): $0.83[3 \mathrm{H}, \mathrm{t}, J=7.8 \mathrm{~Hz}$, $\mathrm{C}_{3}\left(\mathrm{CH}_{2}\right)_{3} \mathrm{O}-$ ], 1.25 [2H, sextet, $J=7.8 \mathrm{~Hz}, \mathrm{CH}_{3} \mathrm{CH}_{2}\left(\mathrm{CH}_{2}\right)_{2} \mathrm{O}-$ ], $1.50(2 \mathrm{H}$, $\left.\mathrm{m}, \mathrm{CH}_{3} \mathrm{CH}_{2} \mathrm{CH}_{2} \mathrm{CH}_{2} \mathrm{O}-\right), 3.47\left(1 \mathrm{H}, \mathrm{dd}, J=9.0,9.0 \mathrm{~Hz}, 3^{\prime \prime}-\mathrm{H}\right), 3.54(1 \mathrm{H}, \mathrm{dd}$, $\left.J=9.0,7.8 \mathrm{~Hz}, 2^{\prime \prime}-\mathrm{H}\right), 3.60\left(1 \mathrm{H}, \mathrm{dd}, J=9.6,9.0 \mathrm{~Hz}, 4^{\prime \prime}-\mathrm{H}\right), 3.74(1 \mathrm{H}, \mathrm{d}$, $\left.J=9.6 \mathrm{~Hz}, 5^{\prime \prime}-\mathrm{H}\right), 4.06\left[2 \mathrm{H}, \mathrm{t}, J=6.6 \mathrm{~Hz}, \mathrm{CH}_{3}\left(\mathrm{CH}_{2}\right)_{2} \mathrm{CH}_{2} \mathrm{O}-\right], 5.28(1 \mathrm{H}, \mathrm{d}$, $\left.J=7.8 \mathrm{~Hz}, 1^{\prime \prime}-\mathrm{H}\right), 6.19(1 \mathrm{H}, \mathrm{d}, J=1.8 \mathrm{~Hz}, 6-\mathrm{H}), 6.38(1 \mathrm{H}, \mathrm{d}, J=1.8 \mathrm{~Hz}, 8-\mathrm{H})$ $6.84\left(1 \mathrm{H}, \mathrm{d}, J=8.4 \mathrm{~Hz}, 5^{\prime}-\mathrm{H}\right), 7.60\left(1 \mathrm{H}, \mathrm{d}, J=1.8 \mathrm{~Hz}, 2^{\prime}-\mathrm{H}\right), 7.61(1 \mathrm{H}, \mathrm{dd}$, $J=8.4,1.8 \mathrm{~Hz}, 6{ }^{\prime}-\mathrm{H}$ ). ${ }^{13} \mathrm{C}-\mathrm{NMR}$ (in $\mathrm{CDCl}_{3} ; 150 \mathrm{MHz}$ ): $159.2(\mathrm{C}-2), 135.4$ (C-3), 179.3 (C-4), 163.1 (C-5), 100.0 (C-6), 166.0 (C-7), 94.8 (C-8), 158.5 (C-9), 105.6 (C-10), 122.9 (C-1'), 117.2 (C-2'), 146.0 (C-3'), 149.9 (C-4'), $116.0\left(\mathrm{C}-5^{\prime}\right), 123.5\left(\mathrm{C}-6^{\prime}\right), 104.5\left(\mathrm{C}-1^{\prime \prime}\right), 75.4\left(\mathrm{C}-2^{\prime \prime}\right), 77.5\left(\mathrm{C}-3^{\prime \prime}\right), 72.7(\mathrm{C}-$ $4^{\prime \prime}$ ), 77.3 (C-5"), 170.2 (C-6"), 66.3 (butyl C-1), 31.5 (butyl C-2), 20.0 (butyl C-3), 14.0 (butyl C-4). The compound having the same structure as 6 was recently isolated from leaves of P. tricuspidata (Vitaceae). ${ }^{8)}$

Acknowledgments This work was supported in part by a Grant-in-Aid for International Scientific Research (No. 09041194) from the Ministry of Education, Culture, Sports, Science, and Technology in Japan. Thanks are due to Dr. Robert P. Adams, Director of the Pacific Center for Molecular Biodiversity, Bishop Museum, U.S.A., for identification of the plant.

\section{References}

1) Munz P. A., "Shore Wildflowers of California, Oregon and Washington," University of California Press, Los Angeles, 1964, pp. 18, 43.

2) Pretsch E., Clerc T., Seibl J., Simon W., "Tables of Spectral Data for Structure Determination of Organic Compounds," 2nd English Edition, ed. by Fresenius W., Huber J. F. K., Pungor E., Rechnitz G. A., Simon W., West Th. S., Springer-Verlag, London, 1989, pp. C186C193.

3) Budzikiewicz H., Djerassi C., Williams D. H., "Structure Elucidation of Natural Products by Mass Spectrometry," Holden-Day, Inc., San Francisco, 1964, pp. 122-127.

4) Kundu A. P., Mahato S. B., Phytochemistry, 32, 999-1002 (1993).

5) Ahmad V. U., Atta-ur-Rahman, "Handbook of Natural Products Data: Pentacyclic Triterpenoids," Vol. 2, Elsevier, Amsterdam, 1994, p. 320.

6) Mohle B., Heller W., Wellmann E., Phytochemistry, 24, 465-467 (1985).

7) Hiermann A., Reidlinger M., Juan H., Sametz W., Planta Med., 57, $357-360$ (1991).

8) Hwang H. K., Sung H. K., Whang W. K., Kim I. H., Yakhak Hoechi 39, 289-296 (1995) [in Korean]. 